\title{
Cysteine addition on short-term cooled boar semen preservation and its relationship with swine field fertility ${ }^{1}$
}

\author{
Carolina K. Severo², Gabriel R. Pereira ${ }^{2}$, Andressa M. Pereira ${ }^{2}$, Gustavo F. Ilha ${ }^{2}$, João Francisco \\ C. de Oliveira ${ }^{2}$, Marcelo Soares ${ }^{3}$, Rubens P. de Arruda ${ }^{3}$ and Paulo B.D. Gonçalves ${ }^{2 *}$
}

\begin{abstract}
Severo C.K., Pereira G.R., Pereira A.M., Ilha G.F., Oliveira J.F.C., Soares M., Arruda R.P. \& Gonçalves P.B.D. 2011. Cysteine addition on short-term cooled board semen preservation and its relationship with swine field fertility. Pesquisa Veterinária Brasileira 31(Supl.1):25-32. Laboratório de Biotecnologia e Reprodução Animal, Departamento de Clínica de Grandes Animais, Hospital Veterinário, Prédio 97, Universidade Federal de Santa Maria, Av. Roraima 1000, Santa Maria, RS 97105-900, Brazil. E-mail: bayard@biorep.ufsm.br

Artificial insemination is routinely used in the swine industry to reduce the costs of production through to increase the efficiency of the refrigerated boar semen process. The objective of this study was to evaluate the effect of different levels of cysteine (CYS) added to the Beltsville Thawing Solution (BTS) extender semen during cooling for up to 72 hours. Ejaculated from three boars were collected with the gloved-hand technique and semen aliquots were diluted in BTS as follow: BTS only (BTS), BTS $+0.1 \mathrm{mM}$ cysteine (CYS0.1), BTS $+0.5 \mathrm{mM}$ cysteine (CYS0.5), BTS $+1.0 \mathrm{mM}$ cysteine (CYS1.0), BTS $+2.5 \mathrm{mM}$ cysteine (CYS2.5), BTS + $5.0 \mathrm{mM}$ cysteine (CYS5.0), BTS $+10.0 \mathrm{mM}$ cysteine (CYS10.0), and BTS $+20.0 \mathrm{mM}$ cysteine (CYS20.0). Evaluation of sperm integrity were analyzed using $0.5 \mathrm{mg} / \mathrm{ml}$ propidium iodide (plasma membrane), $100 \mu \mathrm{g} / \mathrm{ml}$ isothiocynate-conjugated Pisum sativun agglutinin (acrosomal membrane) and $153 \mu \mathrm{M}$ 5,5',6,6'-tetrachloro-1,1',3,3'-tetraethylbenzimidazolyl carbocyanine iodide (mitochondria potential) after semen dilution at specific times $(0,24,48$ and 72 hours). Additionally, we also evaluated the effects of $5.0 \mathrm{mM} \mathrm{CYS}$ addition in the BTS extender on the maintenance of sperm quality and their influence on fertility in the swine production. After artificial insemination, animals were evaluated based on the estrous return and the number of piglet's born. Cysteine at concentrations of 10.0 and $20.0 \mathrm{mM}$ resulted in more pronounced reductions even at the time zero. Semen viability decreased to levels below $10 \%$ at these high levels of CYS in the first 24 hour of storage at $17^{\circ} \mathrm{C}$. At the end of the storage time, less than $65 \%$ of sperm cells had intact plasma membrane in all groups. The sperm viability decreased significantly when the semen was added at high concentrations of CYS (time "0"; CYS10.0 and CYS20.0; $p<0.05)$, when compared to the other CYS concentrations. The BTS $(10.20 \pm 0.39)$ treated group showed a lower rate of estrus return when compared to other (BTSCYS; 86.05 \pm 039 ), and it showed also the highest total number of piglets borne per treatment $(12.71 \pm 3.38 v s .9 .00 \pm 3.38$, respectively). In conclusion, the addition of CYS in the BTS semen extender did not maintain spermatic viability of boar cooled spermatozoa and it results in a higher percentage of return to estrus and lower number of piglets borne.
\end{abstract}

INDEX TERMS: Cysteine, swine spermatozoa, beltsville thawing solution, functional membrane integrity, swine industry.

1 Received on July 15, 2011.

Accepted for publication on November 3, 2011.

2 Laboratório de Biotecnologia e Reprodução Animal, Departamento de Clínica de Grandes Animais, Hospital Veterinário, Prédio 97, Universidade Federal de Santa Maria (UFSM), Av. Roraima 1000, Santa Maria, RS 97105900, Brazil.* Corresponding author: bayard@ufsm.br

3 Laboratório de Andrologia Animal, Departamento de Reprodução Animal, Faculdade de Medicina Veterinária e Zootecnia (FMVZ), Universidade de São Paulo (USP), Av. Duque de Caxias Norte 225, Cx. Postal 23, Pirassununga, SP 13630-000, Brazil.
RESUMO.- [Adição de cisteína na preservação de sêmen suíno refrigerado e sua relação com a fertilidade suína.] A inseminação artificial é usada rotineiramente na indústria suinícula para reduzir os custos de produção além de obter maior eficiência reprodutiva durante o processo de resfriamento do sêmen. O objetivo deste trabalho foi avaliar o efeito da adição de diferentes concentrações de cisteína (CIS) ao diluidor de sêmen Beltsville Thawing Solution (BTS) resfriado sobre a qualidade espermática por até 72 horas. Foram 
coletados ejaculados de três cachaços e as amostras de sêmen foram diluídas em BTS, conforme os seguintes tratamentos: BTS (grupo controle); CIS0,1 (BTS $+0,1 \mathrm{mM}$ de cisteína); CIS0,5 (BTS + 0,5mM de cisteína); CIS1,0 (BTS + 1,0mM de cisteína); CIS2,5 (BTS $+2,5 \mathrm{mM}$ de cisteína); CIS5,0 (BTS + 5,0mM de cisteína); CIS10,0 (BTS + 10,0mM de cisteína) e CIS20,0 (BTS + 20,0mM de cisteína). A avaliação da integridade espermática foi determinada através de sondas fluorescentes em uma combinação de $100 \mu \mathrm{g} / \mathrm{mL}$ FICT-PSA (isotiocinato de lecitina), $0.5 \mathrm{mg} / \mathrm{ml}$ PI (iodeto de propidio), e $153 \mu \mathrm{M}$ JC-1 (5,5',6,6'-tetracloro-1,1',3,3'-tetraetillbenzimidazolil iodeto de carbocianina). As avaliações dos tratamentos foram realizadas $0,24,48$ e 72 horas após a diluição do sêmen. Adicionalmente, foi avaliado o efeito da adição de $5,0 \mathrm{mM}$ de cisteína ao diluidor BTS na manutenção da qualidade espermática e no efeito na fertilidade em suínos. Após a inseminação artificial, as fêmeas foram avaliadas quanto a taxa de retorno e o tamanho da leitegada. Durante todos os períodos analizados, os grupos CIS10,0 e CIS20,0 apresentaram menor número de espermatozóides viáveis em relação aos demais grupos. A viabilidade espermática diminuiu a níveis abaixo de $10 \%$ nos tratamentos CIS10,0 e CIS20,0 nas primeiras 24 horas de armazenamento a $17^{\circ} \mathrm{C}$. Ao final do período de armazenamento todos os grupos apresentavam média inferior a $65 \%$ de espermatozóides com a membrana plasmática intacta. A viabilidade espermática diminuiu significativamente quando altas concentrações de CIS (hora " 0 "; CIS10,0 e CIS20,0; $p<0.05$ ) foram adicionadas ao sêmen comparadas com as demais concentrações. O grupo BTS $(10,20 \pm 0,39)$ apresentou menor taxa de retorno ao estro comparado com BTSCIS $(86,05 \pm 0,39)$, além de apresentar maior número de leitões nascidos $(12,71 \pm 3,38 v s$. $9,00 \pm 3,38$, respectivamente). Portanto, podemos concluir que a adição de CIS ao diluidor BTS não mantém a qualidade espermática e resulta em maior taxa de retorno ao estro e menor número de leitões nascidos.

TERMOS DE INDEXAÇÃO: Cisteína, centrifugação, sêmen resfriado, Beltsville Thawing Solution, suínos.

\section{INTRODUCTION}

Artificial insemination is a widespread technique used in the swine industry to reduce production costs and to achieve a better use of the male gametes into swine production. Semen extended in a liquid state is considered an efficient method to preserve spermatozoa viability and is commonly used to transport semen over long distances (Gadea 2003). This technology is used by the swine industry to produce an adequate environment for short-term storage; however, sperm cells lipid composition of the plasma membrane are sensitive to cold chock that leads to irreversible damage to the spermatozoa membrane and consequently decreases its fertilization potential (Johnson et al. 2000). The temperature of storage $\left(<15^{\circ} \mathrm{C}\right)$ influences the maintenance of boar semen preservation that results in the transition from a fluid to a gel phase that significantly decreases the spermatozoa viability (De Leeuw et al. 1990, Johnson et al. 2000).

The susceptibility of boar spermatozoa to oxidative damage is attributed to the high concentration of polyunsaturated fatty acids (PUFA) in membrane phospholipids and to the limited antioxidant capacity of spermatozoa to generate reactive oxygen species (ROS) (Cerolini et al. 2000, Henkel 2005). The high content of PUFA promotes lipid peroxidation of the sperm plasma membrane, which is crucial to decrease sperm metabolism, motility and fertilization potential (Storey 1997). Kumaresan et al. (2009) observed a decrease on sperm function and on membrane integrity associated with high levels of lipid peroxidation, which occurs during the semen storage period. Efforts to improve the preservation of cooled boar semen have focus on the addition of specific antioxidants to extended semen with the purpose to maintain cell membrane integrity, prevent oxidative stress and preserve spermatozoa motility (Maxwell et al. 1996, Dube et al. 2004).

Spermatozoa are capable of generating ROS that may have physiologic functions in signaling events to control sperm capacitation, acrosome reaction, hyperactivation and sperm-oocyte fusion (Aitken 1995, Aitken et al. 1997, Ball et al. 2001). The use of antioxidants is of fundamental importance to maintain ejaculated-sperm viability (Henkel 2005). In this manner, thiols are part of a large class of antioxidants essential for protein function, including cysteine (CYS), $N$-acetylcysteine (NAC) and glutathione (GSH) (Bilodeau et al. 2001, Goodrowe et al. 2001). Both, the CYS and NAC, are precursors of the biosynthesis of intracellular GSH, and they represent an important molecule at lower levels in spermatozoa. The CYS and NAC act as a cell membrane protector through the maintenance of sulphydric $(-\mathrm{SH})$ groups and they are also known to interact with free radical to decrease the oxygen reactions responsible for the lipid peroxidation and consequently to decrease its spermatozoa function. Apparently, both thiols can reduce the toxic effect of the ROS during the sperm cryopreservation process ( Bilodeau et al. 2001, Thuwanut et al. 2008, Awda et al. 2009). Therefore, antioxidants are crucial to rescue the excessive production of free radicals that are responsible to lipid peroxidation on the damage of the plasma membrane spermatozoa (Baumber et al. 2000).

The Beltsville Thawing Solution (BTS) is a world widely extender used in the swine industry that contains glucose as the main source of semen energy and helps to maintain the viability of semen over time for up to 72 hours at temperature ranging from 15 to $20^{\circ} \mathrm{C}$ (Pursel \& Johnson 1975, Huo et al. 2002). The BTS extender is considered to have a short action and is commonly used when low levels of potassium is present in semen to achieve its intracellular concentration at the physiological levels during storage (Gaczarzewicz et al. 2003). Despite considerable progress in knowledge, there still a little academic research being conducted to establish appropriate protocols in order to benefits the commercial swine industry.

In humans, the administration of NAC to man diagnosed with idiopathic infertility significantly improved semen volume, motility and viscosity based on the reduction of ROS in the serum (Ciftci et al. 2009). Therefore, this reduction of ROS by the addition of antioxidants might be a useful approach in treating male factor infertility. The CYS concentration observed in the ejaculate and spermatozoa of subfertile men was also higher compared with men in the 
idiopathic subfertile group (Ebisch et al. 2006). Funahashi Sano (2005) concluded that the addition of $5.0 \mathrm{mM}$ of CYS in boar ejaculated semen supplemented with Modena extender, which contain $20 \%$ of seminal plasma, maintained viability, integrity and penetration of spermatozoa observed in vitro.

A wide array of antioxidant has been used to prevent oxidative stress in semen from variety of species such as in ruminants (Maxwell \& Stojanov 1996, Nair et al. 2006) and in horses (Ball et al. 2001); however, few reports have addresses their implication in preservation of boar semen in swine. Therefore, the aim of the present study is to evaluate the effects of CYS addition in the BTS extender on the maintenance of sperm quality and their influence on swine fertility.

\section{MATERIALS AND METHODS}

Unless otherwise stated, all media components were purchased from Sigma (Sigma-Aldrich, São Paulo, SP, Brazil). All animal experiments followed a protocol approved by the Committee of Ethics and Animal Welfare in Federal University of Santa Maria and were controlled by the Guidelines for Animal Experiments of the Committee (Protocol \#23081.006881).

Three experiments were conducted to elucidate the potential role of the CYS used as an antioxidant in combination with BTS extender. In the Experiment 1, we evaluated the effect of different concentrations of CYS added to the BTS extender semen during cooling for up to 72 hours. The Experiment 2 was design to evaluate the addition of $5.0 \mathrm{mM}$ of CYS in combination with BTS extender on sperm integrity. Then, the Experiment 3 was conducted in a Producing Unit of Piglets (UPL) at The Cooperative Languiru located in Teutonia, RS, Brazil, to evaluate the potential effect of CYS treatments on the reproductive performance of sows.

\section{The effect of different concentrations of CYS added to the BTS extender (Experiment 1)}

Three boars at the age of 24 months were housed individually and submitted to two semen collections during this study. Fresh clean water was provided ad libitum with automated watering devices throughout the entire trial period. Semen collections were performed using a gloved-hand technique described by Hancock and Hovel (Hancock \& Hovel 1959). The first ejaculatory portion was discharged and the semen was filtered through four $130-\mathrm{mm}^{2}$ gauze at the time of collection. Only the rich fraction was used in this study.

Semen was divided in eight sperm fractions and raw semen motility $>80.0 \%$ was observed subjectively in all fractions. The BTS extender used in this study consisted of $206.0 \mathrm{mM}$ Glucose, $20.4 \mathrm{mM} \mathrm{Na}_{3}$ citrate, $14.9 \mathrm{mM} \mathrm{NaHCO}, 3.4 \mathrm{mM} \mathrm{Na}$ EDTA, $10.0 \mathrm{mM}$ $\mathrm{KCl}$, penicillin- $\mathrm{G} 0.6 \mathrm{~g} / \mathrm{L}$, dihydroestreptomicin $1.0 \mathrm{~g} / \mathrm{L}$ (Minitub, Tiefenbach, Germany) and it was diluted in warmed tridestilated water at $34^{\circ} \mathrm{C}$ at proportion of $50.0 \mathrm{~g} / \mathrm{L}$. To evaluate sperm concentration, $10 \mu \mathrm{l}$ of each ejaculated was diluted $(1: 100)$ in formaldehyde-citrate buffered solution and the number of spermatozoa/ $\mathrm{ml}$ was assessed using a NeuBauer haemocytometer chamber (Boeco, Hamburg, Germany). The final concentration of extended semen was adjusted to $3 \times 10^{9}$ spermatozoa for each $80 \mathrm{ml}$. After, semen aliquots were submitted to different treatments groups as follow: control group, semen diluted in BTS without cysteine (BTS), semen diluted in BTS containing $0.1 \mathrm{mM}$ (CYSO.1), $0.5 \mathrm{mM}$ (CYS0.5), 1.0mM (CYS1.0), 2.5mM (CYS2.5), 5.0mM (CYS5.0), $10.0 \mathrm{mM}$ (CYS10.0) and 20.0mM (CYS20.0) of cysteine. Then, sam- ples were cooled, kept into a refrigerated chamber at $17^{\circ} \mathrm{C}$, and evaluated at $0,24,48$ and 72 hours of storage.

Spermatozoa viability based on spermatozoa staining and fluorescence assessment was evaluated by the plasma membrane integrity (PI), acrossomal membrane integrity (AI), and mitochondrial potential (MP), using fluorescent probes. One aliquot of semen was diluted into Modified Tyrode's Medium (TALP) in order to obtain $25 \times 10^{6}$ spermatozoa/ml. Then, a $150 \mu \mathrm{l}$ aliquot was combined with $3 \mu \mathrm{l}$ of propidium iodide diluted in $5 \mathrm{mg} / \mathrm{l}$ of Dulbecco's phosphate-buffered saline solution (DPBS), $50 \mu \mathrm{l}$ of fluorescein isothiocynate-conjugated Pisum sativun agglutinin (FITC-PSA) in $5 \mathrm{mg} / \mathrm{l}$ of DPBS, and $3 \mu \mathrm{l}$ of 5,5,6,6'-tetrachloro$-1,1,3,3^{\prime}$-tetraethylbenzimidazolyl carbocyanine iodide (JC-1) in $153 \mu \mathrm{M}$ of dimethyl sulphoxide (DMSO) and mixed within the aliquot. Samples were maintained in a dark chamber at room temperature for 8 minutes. After, one aliquot of $7 \mu \mathrm{l}$ was evaluated under epifluorescence microscope (Carl Zeiss) using a triple filter (D/F/R, C58420) set with UV-2E/C (340-380 nm excitation and 435-485 $\mathrm{nm}$ emission), B-2E/C (465-495 $\mathrm{nm}$ excitation and 515$555 \mathrm{~nm}$ emission), and G-2E/C (excitation 540-525 and emission 605-655). Samples were evaluated at x1000 magnification and a total of 200 cells were counted for each treatment group. Spermatozoa were classified according to De Andrade et al. (2007) as viable (intact plasma membrane, intact acrosomal membrane and high mitochondrial function, IPIAH) and not viable (intact plasma membrane, intact acrosomal membrane and low mitochondrial function, IPIAL; intact plasma membrane, damaged acrosomal membrane and enhanced mitochondrial function, IPDAH; intact plasma membrane, damaged acrosomal membrane and decreased mitochondrial function, IPDAL; damaged plasma membrane, intact acrosomal membrane and high mitochondrial function, DPIAH; damaged plasma membrane, intact acrosomal membrane and decreased mitochondrial function, DPIAL; damaged plasma membrane, damaged acrosomal membrane and enhanced mitochondrial function, DPDAH; damaged plasma membrane, damaged acrosomal membrane and decreased mitochondrial function, DPDAL).

\section{The addition of $5.0 \mathrm{mM}$ of CYS on sperm integrity (Experi- ment 2)}

Three boars at the age of 36 months were allocated in individual cages and collected five times during this experiment. Animals were maintained at good corporal condition and fresh clean water was available ad libitum throughout the entire trial period. Semen collection was performed using the same technique as described in Experiment 1. Semen was divided in two fractions and aliquots were submitted to different treatments groups as follow: 1) semen diluted in BTS (BTS); and 2) semen diluted in BTS containing $5.0 \mathrm{mM}$ cysteine (BTSCYS). After, samples were stored into a refrigerated chamber at $17^{\circ} \mathrm{C}$ and evaluated at 0,24 , 48 and 72 hours. Spermatozoa fluorescence assessment was evaluated by the PI, AI, and MP evaluation using fluorescent probes and classified according to describe by Andrade et al. (2007).

\section{The potential effect of CYS treatments on the reproductive performance of sows (Experiment 3)}

Five hybrid males aged over 24 months, four Agroceres and one Geneticpork genetics, maintained at good corporal condition were used throughout the entire trial period. Animals were allocated in the Insemination Center within the UPL Cooperative Languiru. After collection, semen was divided between treatments, BTS and BTSCYS. The BTS extender was prepared in advance and kept at $34^{\circ} \mathrm{C}$ before semen dilution. Then, semen was divided in two aliquots and diluted to obtain $3.5 \times 10^{9}$ sperm for each $90 \mathrm{ml}$. 
One aliquot was used to inseminate the sows and the other was sent to the laboratory at UFSM to evaluate sperm integrity using fluorescents probes as describe earlier.

A total of 91 females were previously selected on the basis of genetics (Debrecht 90 and Cambrough 25), the order of parturition (between three and six) and the weaning estrus interval (between three and five days). Then, females were subdivided into two insemination treatments as follow: semen diluted in BTS (control, $\mathrm{n}=49$ ) and semen diluted in BTS added 5.0mM of CYS (BTSCYS, $n=42$ ). Three cervical inseminations per animal were performed from each treatment group after detection of estrus. Semen used for insemination was stored from 0 to 24 hours at $17^{\circ} \mathrm{C}$. After the inseminations all females were assessed for estrus return and females that returned were not inseminated again. Therefore, females do not return estrus was assessed for the total number of piglets born.

\section{Statistical analysis}

In the Experiment 1 and 2, data was statistically analyzed using a repeated measurement analysis approach to determine the effect of each treatment on each dependent variable, using PROC MIXED of SAS software (SAS Institute, Cary, NC, USA). In the Experiment 3, the effect of treatment on each dependent variable was analyzed using a model of analysis for unbalanced data (PROC GLM - SAS software) to determine the effects of treatment and genetics. The means for the effect of different treatments and genetics in relation to the order of birth, rate of return and number of piglets were compared using the Tukey test. Differences were considered to be significant when $p<0.05$ and results were expressed as mean \pm standard error of means (SEM).

\section{RESULTS}

Spermatozoa fluorescent analyses are shown in Figure 1. Treated-semen groups showed a significant decrease on viable sperm over time (Fig.2). The sperm viability decreased significantly when the semen was added at high concentrations of CYS immediately after dilution (CYS10.0 and CYS20.0; $p<0.05$ ), when compared to the other CYS concentrations. After 72 hours of storage, the sperm viability was below $60 \%$ when the cysteine concentrations were from 0 to $5.0 \mathrm{mM}$ and below $10 \%$ at 10.0 and $20.0 \mathrm{mM}$. The percentage of sperm with plasma membrane integrity decreased over time and was significant lower in CYS20.0 at 24 and 48 hours and in CYS10.0 and CYS20.0 at 72 hour $(p<0.05)$ (Fig.3A). The acrosome membrane integrity was also lower in CYS20.0 from 0 to 48 hours $(p<0.05)$. The integrity of the acrossomal membrane rate was also lower in CYS10.0 at 0 hour $(p<0.05)$. The groups BTS, CYS0.1, CYS0.5, CYS1.0, CYS2.5, CYS5.0 and CYS10.0 yielded higher than $60 \%$ of damage in the integrity of acrossomal membrane after 72 hours of storage at $17^{\circ} \mathrm{C}$ (Fig.3B). The number of sperm with mitochondrial potential was lower in CYS10.0 and CYS20.0 from 0 to 72 hours when compared to other groups $(p<0.05)$ (Fig.3C). In Experiment 2, all treatments showed a reduction in the percentage of sperm with intact membranes and mitochondrial potential during the period of storage at $17^{\circ} \mathrm{C}$; however no differences was observed among treatments (Fig.4A-C). In Experiment 3, the
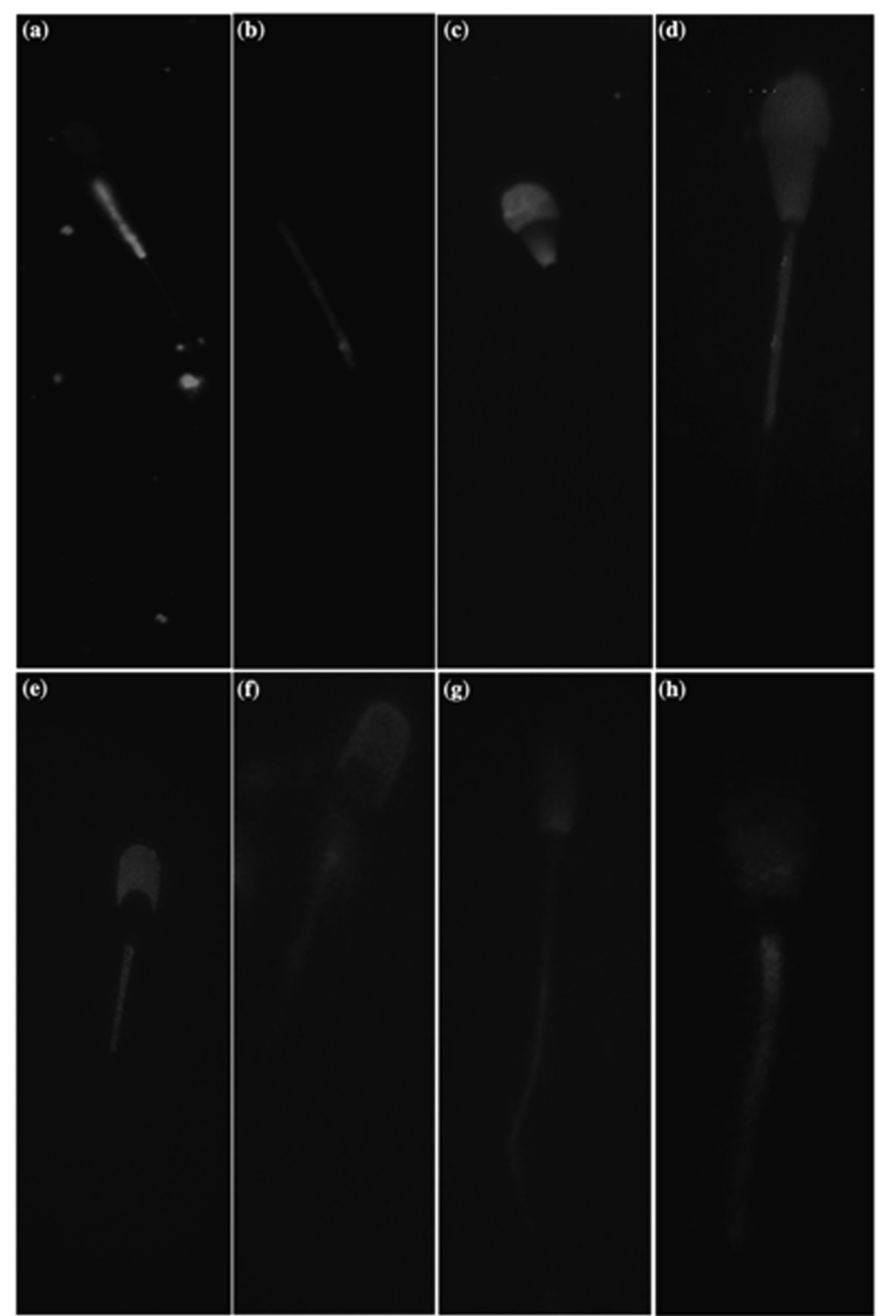

Fig.1. Epifluorescence photomicrography of sperm cells stained with the association of fluorescent probes: PI (stain: red), FITC (stain: green), and JC-1 (stain: orange). (a) Intact plasma membrane, intact acrosomal membrane and high mitochondrial function (IPIAH). (b) Intact plasma membrane, intact acrosomal membrane and low mitochondrial function (IPIAL). (c) Damaged plasma membrane, damaged acrosomal membrane and low mitochondrial function (DPDAL). (d) Damaged plasma membrane, damaged acrosomal membrane and high mitochondrial function (DPDAH). (e) Intact plasma membrane, damaged acrosomal membrane and high mitochondrial function (IPDAH). (f) Intact plasma membrane, damaged acrosomal membrane and low mitochondrial function (IPDAL). (g) Damaged plasma membrane, intact acrosomal membrane and low mitochondrial function (DPIAL). (h) Damaged plasma membrane, intact acrosomal membrane and high mitochondrial function (DPIAH). Bars represent $10 \mathrm{~nm}$.

mean semen viability after 24 hours were $17.61 \%$ BTS and $10.86 \%$ BTSCYS. The genetic did not influence the rate of estrus return neither the number of piglets' borne. The order of parturition and the interval of estrus return did not

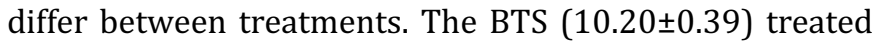
group showed a lower rate of estrus return when compared to BTSCYS (86.05 \pm 0.39$)$, and it showed also the highest total number of piglets borne per treatment $(12.71 \pm 3.38$

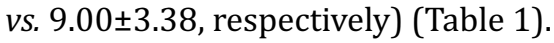




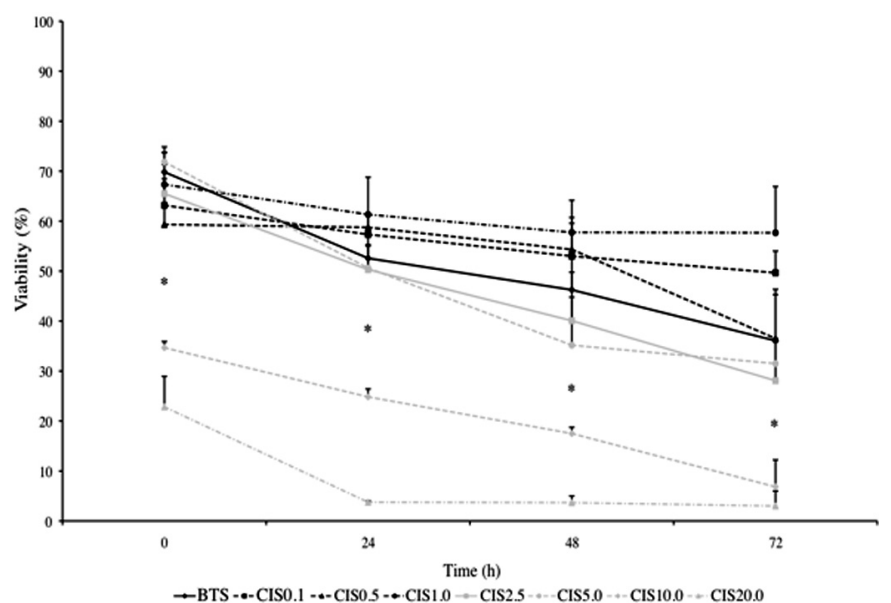

Fig.2. The effect of different concentration of cysteine added to Beltsville Thawing Solution extender on spermatozoa viability of swine semen storage at $17^{\circ} \mathrm{C}$ for 72 hours. * Indicates difference between treatments $(p<0.05)$. (CYS: Cysteine; BTS: Beltsville Thawing Solution)

\section{DISCUSSION}

In the present study, the effect of different concentrations of CYS on the viability was investigated in sperm cells after cooling boar semen for up to 72 hours. We demonstrated that CYS has a deleterious effect in a dose dependent manner on swine sperm cells maintained at $17^{\circ} \mathrm{C}$ for a short period of storage. We also observed that all semen parameters evaluated in the present study were affected by high concentrations of CYS (10.0 and $20.0 \mathrm{mM})$. In contrast, the CYS added to BTS in low concentrations, from 0.1 to 1.0 $\mathrm{mM}$, did not have any effect on sperm viability when boar semen was storage for 72 hours at $17^{\circ} \mathrm{C}$. The temperature of $17^{\circ} \mathrm{C}$ used in this study is considered adequate for boar semen storage for up to three days using the BTS extender (Dube et al. 2004, Johnson et al. 2000). Liquid boar semen is commonly stored at temperatures between 15 and $20^{\circ} \mathrm{C}$ for using in artificial insemination at the swine industry; however, temperatures below $15^{\circ} \mathrm{C}$ may impair sperm cell viability during storage (Althouse et al. 1998).

Funahashi \& Sano (2005) concluded that antioxidants reduce the percentage of defects in acrosome; however, their study used seminal plasma in addition to treated semen which in know to contain active antioxidants enzymes and may obscure the results of CYS. In bovine, the concentration of $0.5 \mathrm{mM}$ of CYS was sufficient to maintain sperm motility in the absence of hydrogen peroxide $\left(\mathrm{H}_{2} \mathrm{O}_{2}\right)$ in semen diluted in TRIS buffer containing egg yolk (Bilodeau et al. 2001). In contrast, we observed that the addition of 5.0 $\mathrm{mM}$ CYS to the BTS extender did not influence the acrossomal membrane integrity. Moreover, in horses (Baumber, et al. 2000) and in rams (Sarlos et al. 2002) there was no effect of CYS on the acrossomal membrane integrity. In man, semen showing with higher concentration of thiols is considered subfertile (Ebisch et al. 2006). Furthermore, investigations of the physiological role of CYS during capacitation and acrosome reaction as well as proteins phosphorylation is needed to improve the understanding of boar sperm function.
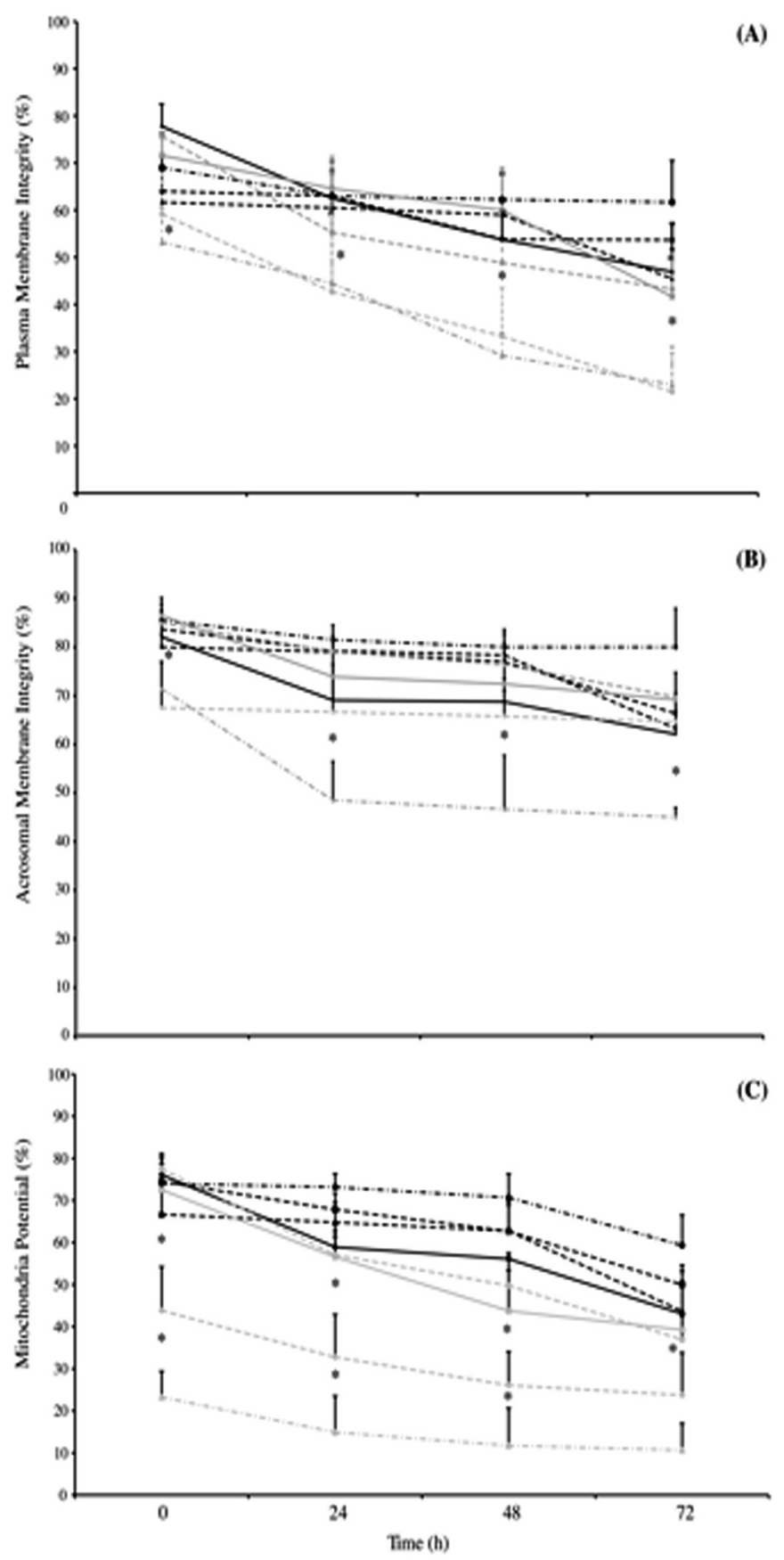

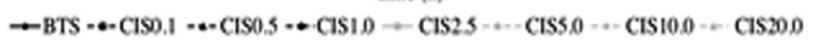

Fig.3. (A) The effect of different concentration of cysteine added to Beltsville Thawing Solution extender on plasma membrane integrity, (B) acrosome membrane integrity, and (C) mitochondria potential of swine semen storage at $17^{\circ} \mathrm{C}$ for 72 hours. * Indicates difference between treatments $(p<0.05)$. (CYS: Cysteine; BTS: Beltsville Thawing Solution)

A variety of newer approaches for the assessment of sperm viability by fluorescent technique in combination with sperm motility parameters are becoming increasingly available to predict fertilization ability and non-return rate after artificial insemination in swine (Juonala et al. 1999, Sutkeviciene et al. 2005, Turba et al. 2007). Beside several organelles in the spermatozoa organization, mitochondria is known to promote oxidative phosphorylation and also to 
produce energy from adenosine tri-phosphate (ATP) that is critical for cell motility (Oura \& Toshimori 1990, Frey \& Mannella 2000). In the current study, the presence of mitochondrial potential showed similar parameters observed on studies in bovine semen (Celeghini et al. 2008). According Peña et al. (2003), the maintenance of mitochondria function of boar spermatozoa depends of the protector effect of the antioxidants. Of this, the potential of mitochon-
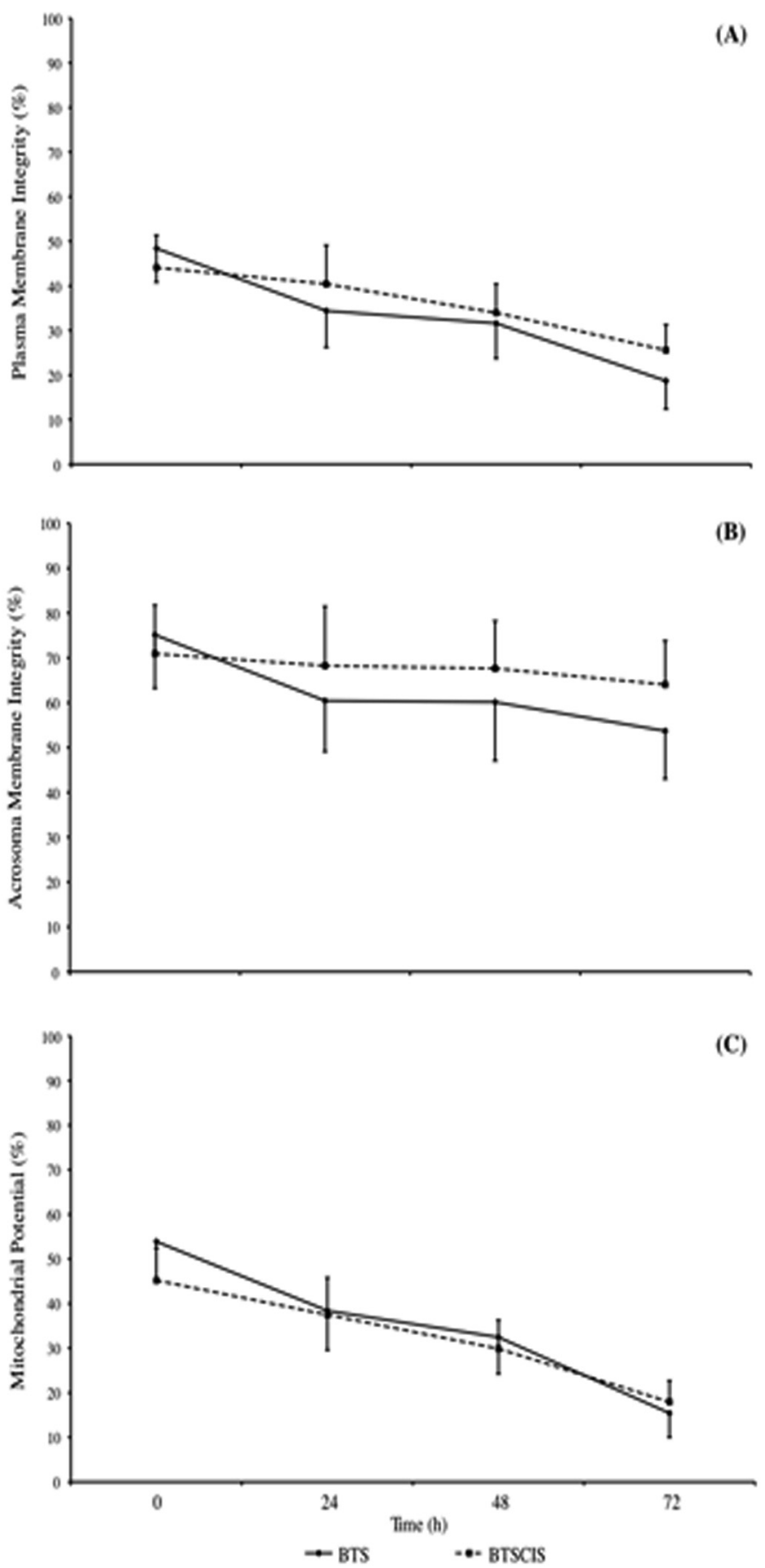

Fig.4. (A) The effect of $5.0 \mathrm{mM}$ of cysteine added to Beltsville Thawing Solution extender on plasma membrane integrity, (B) acrosome membrane integrity, and (C) mitochondria potential of swine semen storage at $17^{\circ} \mathrm{C}$ for 72 hours. * Indicates difference between treatments $(p<0.05)$. (CYS: Cysteine; BTS: Beltsville Thawing Solution)
Table 1. The effect of cysteine addition into the Beltsville Thawing Solution extender on the rate of estrous return and on the number of piglets' born

\begin{tabular}{lccc}
\hline Treatments & $\begin{array}{c}\text { Inseminated } \\
\text { sows }(\mathrm{n})\end{array}$ & $\begin{array}{c}\text { Estrous return } \\
\mathrm{n}(\text { mean } \pm \text { SEM) }\end{array}$ & $\begin{array}{c}\text { Piglet's born } \\
\text { n (mean } \pm \text { SEM) }\end{array}$ \\
\hline BTS & 49 & $5(10.20 \pm 0.39)^{\mathrm{a}}$ & $12.7 \pm 3.38^{\mathrm{a}}$ \\
BTSCYS & 42 & $36(86.05 \pm 0.39)^{\mathrm{b}}$ & $9.00 \pm 3.38^{\mathrm{b}}$
\end{tabular}

SEM = Standard error mean, CYS = Cysteine, BTS = Beltsville Thawing Solution. Different letters between treatments $(p<0.01)$.

dria membrane viability can be an important indicator of functional integrity (Cummins et al. 1994). Functional integrity of sperm membranes has been used in horses (Arruda et al. 2007), bovine (Celeghini et al. 2007), swine (Andrade et al. 2007), and humans (Ozaki et al. 2002), to identify "live" and "dead" sperm.

Centrifugation is a process that removes seminal plasma from ejaculated semen with the aim to decrease the deleterious effects of ROS compounds on the spermatozoa (Carvajal et al. 2004). However, the removal of seminal plasma, the mechanical damage and the formation of ROS appear to have negative effect on spermatozoa viability (Alvarez et al. 1993, Katkov \& Mazur 1998). Some species are more sensitive to the process of centrifugation, such as rats (Cardullo \& Cone 1986), human (Ng et al. 1990) and mice (Katkov \& Mazur 1998), whereas cattle (Pickett et al. 1975) and horses (Crockett et al. 2001) are more resistant. This indicates that there is specificity between species according to the centrifugation steps used to separate spermatozoa from seminal plasma. Moreover, the antioxidants have an important function of scavenging the reactive oxygen species that are found on spermatozoa and leukocyte in bovine and boar semen (Ng et al. 1990, Crockett et al. 2001). By the other hand, high concentration of cysteine seems to have a detrimental effect on boar sperm cells maintained at low temperature. In our study, this deleterious effect was not caused by changes in osmolality or $\mathrm{pH}$. The osmolality was around $348 \mathrm{mOsm}$ and $\mathrm{pH}$ between 7.2 and 7.4 in all treatment groups (data not shown). According to Gadea (2003) the pH of boar semen is similar to body fluids and can tolerate a fairly wide range of osmotic pressures (240380 mOsm).

In this study, we evaluated the effect of CYS added to BTS extender on rate of estrus return and the total number of piglets' borned in a herd. These reproductive parameters were also used to assess the influence of different diluents such as BTS, Merk III and coconut water on swine productivity (Kotzias-Bandeira 1999). The current study demonstrates that CYS added to cooled semen for artificial insemination showed a negative effect on the rate return estrous and on the total number of piglet's borned. Beside, Funahashi \& Sano (2005) reported no difference on the penetration of sperm in oocytes between diluted semen using modified Modena extender in the presence or absence of CYS up to eight days of storage at $10^{\circ} \mathrm{C}$. However, the same study showed that until 29 days of semen storage diluted in modified Modena extender and added $5 \mathrm{mM}$ CYS showed the highest rates of sperm penetration. The number of piglets born was higher in BTS compared to BTSCYS, indicating that the absence of CYS may be important to maintain 
the number of piglets' borned. Although this negative effect of CYS on the number of piglets were not expected, when the rate of return was superior over $10 \%$ we pass to consider it. In conclusion, the current study demonstrates that CYS affect the sperm viability resulting in a higher percentage of return to estrus and lower number of piglet's born.

Acknowledgements.- This study was supported by the Brazilian Federal Council for Higher Education Personnel (CAPES) and the National Council for Scientific Research and Development (CNPq). We thank the students Vitor S. Truzzi, Lucas Oberherr , Rosinara S. Costa, Carolini M. Landarin for the help with semen collection.

\section{REFERENCES}

Aitken R.J. 1995. Free radicals, lipid peroxidation and sperm function. Reprod. Fertil. Dev. 7:659-668.

Aitken R.J., Fisher H.M., Fulton N., Gomez E., Knox W., Lewis B. \& Irvine S. 1997. Reactive oxygen species generation by human spermatozoa is induced by exogenous NADPH and inhibited by the flavoprotein inhibitors diphenylene iodonium and quinacrine. Mol. Reprod. Dev. 47:468-482.

Althouse G.C., Wilson M.E., Kuster C. \& Parsley M. 1998. Characterization of lower temperature storage limitations of fresh-extended porcine semen. Theriogenology 50:535-543.

Alvarez J.G., Lasso J.L., Blasco L., Nunez R.C., Heyner S., Caballero P.P. \& Storey B.T. 1993. Centrifugation of human spermatozoa induces sublethal damage; separation of human spermatozoa from seminal plasma by a dextran swim-up procedure without centrifugation extends their motile lifetime. Hum. Reprod. 8:1087-1092.

Andrade A.F., Arruda R.P., Celeghini E.C., Nascimento J., Martins S.M., Raphael C.F. \& Moretti A.S. 2007. Fluorescent stain method for the simultaneous determination of mitochondrial potential and integrity of plasma and acrosomal membranes in boar sperm. Reprod. Domest. Anim. 42:190-194.

Arruda R.P., de Andrade A.F., Peres K.R., Raphael C.F., Nascimento J. \& Celeghini C. 2007. Biotécnicas aplicadas à avaliação do potencial de fertilidade do sêmen eqüino. Rev. Bras. Reprod. Anim. 31:8-16.

Awda B.J., Mackenzie-Bell M. \& Buhr M.M. 2009. Reactive oxygen species and boar sperm function. Biol. Reprod. 81:553-561.

Ball B.A., Medina V., Gravance C.G. \& Baumbe J. 2001. Effect of antioxidants on preservation of motility,viability and acrosomal integrity of equine spermatozoa during storage at 5 degrees C. Theriogenology 56:577589.

Ball B.A., Vo A.T. \& Baumber J. 2001. Generation of reactive oxygen species by equine spermatozoa. Am. J. Vet. Res. 62:508-515.

Baumber J., Ball B.A., Gravance C.G., Medina V. \& Davies-Morel M.C. 2000. The effect of reactive oxygen species on equine sperm motility, viability, acrosomal integrity, mitochondrial membrane potential, and membrane lipid peroxidation. J. Androl. 21:895-902.

Bilodeau J.F., Blanchette S., Gagnon C. \& Sirard M.A. 2001. Thiols prevent H2O2-mediated loss of sperm motility in cryopreserved bull semen. Theriogenology 56:275-286.

Cardullo R.A. \& Cone R.A. 1986. Mechanical immobilization of rat sperm does not change their oxygen consumption rate. Biol. Reprod. 34:820830.

Carvajal G., Cuello C., Ruiz M., Vazquez J.M., Martinez E.A. \& Roca J. 2004. Effects of centrifugation before freezing on boar sperm cryosurvival. J. Androl. 25:389-396.

Celeghini E.C., Arruda R.P., Andrade A.F., Nascimento J. \& Raphael C.F. 2007. Practical techniques for bovine sperm simultaneous fluorimetric assessment of plasma, acrosomal and mitochondrial membranes. Reprod. Domest. Anim. 42:479-488.

Celeghini E.C., de Arruda R.P., Andrade A.F., Nascimento J., Raphael C.F. \& Rodrigues P.H. 2008. Effects that bovine sperm cryopreservation using two different extenders has on sperm membranes and chromatin. Anim. Reprod. Sci. 104:119-131.
Cerolini S., Maldjian A., Surai P. \& Noble R. 2000. Viability, susceptibility to peroxidation and fatty acid composition of boar semen during liquid storage. Anim. Reprod. Sci. 58:99-111.

Ciftci H., Verit A., Savas M., Yeni E. \& Erel 0. 2009. Effects of N-acetylcysteine on semen parameters and oxidative/antioxidant status. Urology 74:73-76.

Crockett E.C., Graham J.K., Bruemmer J.E. \& Squires E.L. 2001. Effect of cooling of equine spermatozoa before freezing on post-thaw motility: preliminary results. Theriogenology 55:793-803.

Cummins J.M., Jequier A.M. \& Kan R. 1994. Molecular biology of human male infertility: links with aging, mitochondrial genetics, and oxidative stress? Mol. Reprod. Dev. 37:345-362.

De Leeuw F.E., Chen H.C., Colenbrander B. \& Verkleij A.J. 1990. Cold-induced ultrastructural changes in bull and boar sperm plasma membranes. Cryobiology 27:171-183.

Dube C., Beaulieu M., Reyes-Moreno C., Guillemette C. \& Bailey J.L. 2004. Boar sperm storage capacity of BTS and Androhep Plus: Viability, motility, capacitation, and tyrosine phosphorylation. Theriogenology 62:874886.

Ebisch I.M., Peters W.H., Thomas C.M., Wetzels A.M., Peer P.G. \& Steegers-Theunissen R.P. 2006. Homocysteine, glutathione and related thiols affect fertility parameters in the (sub)fertile couple. Hum. Reprod. 21:1725-1733.

Frey T.G. \& Mannella C.A. 2000. The internal structure of mitochondria. Trends Biochem. Sci. 25:319-324.

Funahashi H. \& Sano T. 2005. Select antioxidants improve the function of extended boar semen stored at 10 degrees C. Theriogenology 63:16051616.

Gaczarzewicz D., Piasecka M., Udala J., Blaszczyk B., Laszczynska M. \& Kram A. 2003. Oxidoreductive capability of boar sperm mitochondria in fresh semen and during their preservation in BTS extender. Reprod. Biol. 3:161-172.

Gadea J. 2003. Review: Semen extender used in the artificial insemination of swine. Spanish J. Agric. Res. 1:17-27.

Goodrowe K.L., Mastromonaco G.F., Walker S.L., Bateman H.L., Ryckman D.P., Platz Jr C.C. \& Waddell W.T. 2001. In vitro maintenance, cooling and cryopreservation of red wolf (Canis rufus) spermatozoa. J. Reprod. Fertil. Suppl. 57:387-392.

Hancock J.L. \& Hovel G.J.R. 1959. The collection of boar semen. Vet. Rec. 71:664-665.

Henkel R. 2005. The impact of oxidants on sperm function. Andrologia 37:205-206.

Huo L.J., Ma X.H. \& Yang Z.M. 2002. Assessment of sperm viability, mitochondrial activity, capacitation and acrosome intactness in extended boar semen during long-term storage. Theriogenology 58:1349-1360.

Johnson L.A., Weitze K.F., Fiser P. \& Maxwell W.M. 2000. Storage of boar semen. Anim. Reprod. Sci. 62:143-172.

Juonala T., Salonen E., Nurttila T. \& Andresson M. 1999. Three fluorescence methods for assessing boar sperm viability. Reprod. Domest. Anim .34:83-87.

Katkov II \& Mazur P. 1998. Influence of centrifugation regimes on motility, yield, and cell associations of mouse spermatozoa. J. Androl. 19:232-241.

Kotzias-Bandeira E. 1999. Influência de diferentes diluentes e temperaturas de refrigeração sobre a qualidade de sêmen suíno. Braz. J. Vet. Res. Anim. Sci. 36:

Kumaresan A., Kadirvel G., Bujarbaruah K.M., Bardoloi R.K., Das A., Kumar S. \& Naskar S. 2009. Preservation of boar semen at 18 degrees $C$ induces lipid peroxidation and apoptosis like changes in spermatozoa. Anim. Reprod. Sci. 110:162-171.

Maxwell W.M. \& Stojanov T. 1996. Liquid storage of ram semen in the absence or presence of some antioxidants. Reprod. Fertil. Dev. 8:10131020.

Maxwell W.M., Welch G.R. \& Johnson L.A. 1996. Viability and membrane integrity of spermatozoa after dilution and flow cytometric sorting in the presence or absence of seminal plasma. Reprod. Fertil. Dev. 8:1165-1178. 
Nair S.J., Brar A.S., Ahuja C.S., Sangha S.P. \& Chaudhary K.C. 2006. A comparative study on lipid peroxidation, activities of antioxidant enzymes and viability of cattle and buffalo bull spermatozoa during storage at refrigeration temperature. Anim. Reprod. Sci. 96:21-29.

Ng S.C., Bongso T.A., Sathananthan H., Tok V.C. \& Ratnam S.S. 1990. Micro-centrifugation of human spermatozoa: its effect on fertilization of hamster oocytes after micro-insemination spermatozoal transfer. Hum. Reprod. 5:209-211.

Oura C. \& Toshimori K. 1990. Ultrastructural studies on the fertilization of mammalian gametes. Int. Rev. Cytol. 122:105-151.

Ozaki T., Takahashi K., Kanasaki H. \& Miyazaki K. 2002. Evaluation of acrosome reaction and viability of human sperm with two fluorescent dyes. Arch. Gynecol. Obstet. 266:114-117.

Pena F.J., Johannisson A., Wallgren M. \& Rodriguez-Martinez H. 2003. Assessment of fresh and frozen-thawed boar semen using an Annexin-V assay: A new method of evaluating sperm membrane integrity. Theriogenology 60:677-689.

Pickett B.W., Sullivan J.J., Byers W.W., Pace M.M. \& Remmenga E.E. 1975. Effect of centrifugation and seminal plasma on motility and fertility of stallion and bull spermatozoa. Fertil. Steril. 26:167-174.
Pursel V.G. \& Johnson L.A. 1975. Freezing of boar spermatozoa: Fertilizing capacity with concentrated semen and a new thawing procedure. J. Anim. Sci. 40:99-102.

Sarlos P., Molnar A., Kokai M., Gabor G. \& Ratky J. 2002. Comparative evaluation of the effect of antioxidants in the conservation of ram semen. Acta Vet. Hung. 50:235-245.

Storey B.T. 1997. Biochemistry of the induction and prevention of lipoperoxidative damage in human spermatozoa. Mol. Hum. Reprod. 3:203213.

Sutkeviciene N., Andersson M.A., Zilinskas H. \& Andersson M. 2005. Assessment of boar semen quality in relation to fertility with special reference to methanol stress. Theriogenology 63:739-747.

Thuwanut P., Chatdarong K., Techakumphu M. \& Axner E. 2008. The effect of antioxidants on motility, viability, acrosome integrity and DNA integrity of frozen-thawed epididymal cat spermatozoa. Theriogenology 70:233-240.

Turba M.E., Fantinati P., Bernardini C., Gentilini F., Bacci M.L. \& Forni M. 2007. Relationships between innovative and traditional parameters to investigate semen quality in pigs. Anim. Reprod. Sci. 99:7281. 